\title{
Dispute Settlement in Iran's Stock Market
}

\author{
Omid Ghasemi ${ }^{1} \&$ Seyed Mohammad Aghamiri ${ }^{1}$ \\ ${ }^{1}$ Department Law, Islamic Azad University, Ahwaz branch, Ahwaz, Iran \\ Correspondence: Omid Ghasemi, Department Law, Islamic Azad University, Ahwaz branch, Ahwaz, Iran. E-mail: \\ dr_ghassemi@hotmail.com
}

Received: September 4, 2016 Accepted: October 2, 2016 Online Published: December 29, 2016

doi:10.5539/jpl.v10n1p245

URL: http://dx.doi.org/10.5539/jpl.v10n1p245

\begin{abstract}
Arbitration has long been considered by people to settle disputes. Moreover, due to the specific advantages of this method, it has a particular place in different legal systems and it has been attempted to use it in important contexts, even family disputes. Nowadays, arbitration is a significant alternative to settle disputes in a business context. Exchange is one of the crucial fields of domestic and foreign trade. In this regard, the legislature with the goal of using arbitration advantages such as speed, accuracy and expertise, has considered this method to settle exchanged disputes and introduced a committee called "jury" in Securities Market Act enacted in 2005. But it has imposed criteria and rules that made it distinctive from arbitration. This study aimed to study this committee and clarify its legal nature and jurisdiction.
\end{abstract}

Keywords: dispute settlement, legal system, trade, disputes

\section{Introduction}

Wherever a contract or transaction is set, there is a possibility of disputes between dealers. Of course, in stock exchange where the trade (especially securities) is done, problems and disputes are created between the activists where accurate and early settlements will increase efficiency and confidence of the people. Arbitration has long been used to settle problems and disputes. Moreover, due to the specific advantages of this method, it has a particular place in different legal systems and it has been attempted to use it in important contexts, even family disputes. Nowadays, arbitration is a significant alternative to settle disputes in a business context. Exchange is one of the crucial fields of domestic and foreign trade. In this regard, the legislature with the goal of using arbitration advantages such as speed, accuracy and expertise has considered this method to settle exchanged disputes. This study aims to study this committee and clarify its legal nature and jurisdiction.

\section{Statement of the Problem and Purpose of the Study}

Since stock exchange is a financial and specific market and according to the specific features of stock exchanges such as high speed, accuracy, access to all information necessary for traders, transactions by official agencies, specific restrictions for those involved in such transactions, the effects of political, social, economic and military developments on transactions, and the created disputes in these transactions and importance and the necessity to expedite the proceedings, the technical considerations by experts in stock exchange will be unavoidable. The Securities Market Act, enacted in 2005, as the law governing the stock exchange, has determined authorities to investigate the offences. The above law in Article 52 has determined the stock exchange crimes, but in order to investigate the professional disputes by activities in stock exchange, the legislature is considered as the authority with certain formation or appointed members with specific qualifications that is called the jury. Among the issues of interest, one is the difference of this type of arbitration with other arbitrations that, in short, the following differences can be mentioned: 1. Difference: in other arbitrations, the agreement is the qualification of arbitration, but in stock exchange arbitration, the arbiters do not work with satisfaction and based on the contract, but arbitration is an entity that is established by the legislature to settle disputes. 2. Selectivity of arbiters: in other arbitrations, the arbiter is consensual but in stock exchange, the selection of an arbiter is based on the Securities Market Act and among qualified people. 3. Arbitration duration: unlike other arbitrations, there is no need to mention arbitration duration nor making judgments limited to a specific period. Therefore, the following purposes are considered for this study:

1. Investigating and presenting the definition of criteria, characteristics and arbitration circumstances in stock exchange relying on accurate investigation of the nature 
2. Finding similarities and differences of stock exchange arbitration and other arbitrations

3. Finding legal defects and shortcomings and practical problems in the arbitration atmosphere in the stock exchange

\subsection{Significance of the Study}

At the present, in most of the developed countries, the stock exchange markets are considered as the central core of the capital market and each year, an enormous amount of capitals is directed towards generative and active sectors of the society. According to the economic importance of stock exchange, problems among market participants require legal authorities that can settle the problems accurately. Otherwise, the problems and disputes increase that lead to decreased confidence towards stock exchange and this leads to stagnation of the stock exchange. In this regard, the legislature has predicted a specialized pillar as jury to settle disputes.

\subsection{Research Questions and Hypotheses}

The main hypothesis of the study or the proposed question that this study aims to answer is "according to the available regulations and rules, what are the nature, features and characteristics of arbitration in the stock exchange?" There are other questions that will be answered as minor hypotheses: 1 . What are the differences and similarities between arbitration in stock exchange and other arbitrations? 2. What are the scope and authority of a stock exchange jury?

\section{Principles and Concepts}

\subsection{Stock Exchange}

The stock exchange has literal, general and idiomatic definitions. In literal terms, in famous dictionaries such as Moein Dictionary, we have "exchange" and "exchange place" and "exchange system" (Moein, 1984). In legal and economic terms, there are two concepts that are necessary to fully understand stock exchange: 1. Legal term: in Langorodi's terminology, it means the meeting of the Board of Trade permitted by law that gather for trades related to commercial affairs. 2. Economic term: financial sources in societies have owners that are likely willing to bring the sources into circulation and make profits. On the other hand, there are people who are looking for their sources and do not have these sources. Accordingly, it is quite natural that this supply and demand create financial market (Langorodi, 1998).

\subsection{How to Manage Stock Exchange}

The country's stock market has been constituted from two main parts based on law: 1 . The supervisory part that includes the Supreme Council of the Securities and Exchange and the Securities and Exchange Organization. 2. The administrative part that includes stock exchange.

The supervisory system governing the capital market consists of the following cases: 1 . Supreme Council of the Securities and Exchange 2. Board of Directors 3. Head of Organization 4. Auditor

\subsection{The History of Dispute Settlement in Stock Exchange}

The first law that was approved regarding stock exchange was Securities Exchange Establishment Act of 1966 when the stock exchange got a license for activity. After that in 2005, Securities Market Act was approved. In the new law, the transformational disputes were settled. Also, in the third development plan, in order to settle disputes related to shares of public companies, the jury panel was predicted (Darbishi, 2009).

\subsection{Securities Exchange Establishment Act of 1966}

Tehran Stock Exchange (TSE) got its license for establishment and activity by Securities Exchange Establishment Act of 1966. Indeed, this was the first law related to stock exchange in Iran. Although legislation settles most of the problems, disputes cannot be fully settled and usually the regulations are ambiguous and inefficient in some cases (Davati, 1996).

\subsection{Elements of the Former Stock Exchange}

\subsubsection{The Stock Exchange Council}

The stock exchange council as the supreme element of the stock exchange was responsible to supervise stock exchange such as approval of regulations and necessary rules for the implementation of establishment law, supervising the establishment Act implementation and related regulations as well as sending representatives in the Board of Directors and Board of Admissions (Mirzaei, 2011).

\subsubsection{The Admission Panel}

This panel was constituted to approve or reject decisions regarding the admission of securities in stock 
exchanges. All of the admission requests and removal of securities were referred to the admissions panel by the Board of Directors. In the new Securities Market Act, enacted in 2005, the admissions panel lost its place as one of the four pillars of the securities market. Article 30 of the new law about the admission of securities has stated that "the admission of securities in the stock exchange is based on a guideline that will be approved by the organization" (Ibid).

\subsubsection{The Stock Brokers}

According to the Establishment Act, a stock exchange is directed by stock brokers. This organization is a legal entity directed by the Board of Directors of Stock Exchange. The responsibilities of this panel consist of the following cases: 1 . Stock exchange management 2. Representation of stock brokers in all authorities 3 . Handling the brokerage applications and issuing license 4. Regulating and notifying the securities list immediately after each stage 5. Supervising the commitments of stock brokers regarding each other and third parties 6 . Settlement of professional disputes of stock brokers in stock exchange and making decisions regarding their infractions based on stock exchange regulations 7. Provision of stock disciplinary and disciplinary decisions for brokers, staff and other people who are active in the stock exchange (Mirzaei, 2007).

\subsubsection{Jury}

In the Establishment Act, this panel has a certain combination with specific quality. The members of this panel consisted of: 1. A representative of the Department of Justice selected among the heads of branches or a Supreme Court Justice 2. A representative of the Stock Exchange Council 3. A mutual representative of Iran's Chamber of Mines and Tehran's Chamber of Commerce. Article 17 of the Establishment Act, regarding jury states that "stock exchange jury that is constituted permanently, handles the disputes between stock brokers with each other and disputes between sellers or buyers and brokers." According to the Article 17 of the Establishment Act, handling the disputes of both groups was within the jurisdiction of the jury (Fahimi, 2009).

\subsection{Securities Market Act Enacted in 2005}

Regarding the executive policies of the fourth and fifth principle of the constitution and efforts for privatization, the Securities Market Act was enacted in 2005. By this Act, the Establishment Act and the related regulations were abrogated to it. The new Act has determined four pillars for the stock exchange: The Supreme Council of the Securities, Securities and Stock Exchange Organization, Stock Exchange, and Jury. The supreme pillar of the stock is the Supreme Council of Securities and Stock Exchange. The responsibilities of this pillar according to the Article 4 of this Act are listed in Paragraph 16. In addition to supervising the stock exchange, this council is responsible to enact stock macroeconomic policies. One of the differences of the Supreme Council of Securities and Stock Exchange and Council of Stock Exchange in the previous Act relates to the responsibilities of this council and discussion about the selection of jury members. According to the previous Act, the Stock Exchange Council was only an alternative for membership in jury panel, but according to the new Act, the selection of all members and determining their remuneration was among the responsibilities of the Supreme Council of Securities and Stock Exchange. Another pillar of the stock exchange is the Securities and Stock Exchange Organization. This organization has replaced the Stock Exchange Brokers in the old Act. In the old Act, the Stock Exchange Brokers was only supervising the securities and metals and agriculture stocks had independent structure. But in the new Act, all of the stock exchange markets such as securities markets and commodity exchange (commodity exchange is constituted from integrating metals and agriculture stocks) are under the supervision of Securities and Stock Exchange Organization (Madani, 2009).

\subsection{Dispute Settlement Authorities in the New Act}

The Market Act has predicted three authorities to settle the stock exchange dispute: 1. Associations, 2. Jury, and 3. The Board of Directors of Stock Exchange.

\subsubsection{Associations and Jury}

Article 36 of Market Act provides that "disputes between brokers, traders, investment advisors, issuers, investors, and other beneficiaries resulted from their professional activities are handled in the associations by the jury."

The associations do not perform the professional activities of their members such as interventions or issuing securities or other responsibilities that are beyond their jurisdictions. The associations as specialized centers can be highly efficient, because in each dispute, people with expertise handle the issue of interest and this can facilitate the settlement process. Settlements in the associations are done in intervention mode and aim to force parties to compromise. If the settlement is resulted, there is no need for the jury. Otherwise, associations will issue certificate for no compromise. This certificate has two features in order to be admitted by the jury (Fahimi, 2009). 


\subsubsection{The Board of Directors of Stock Exchange}

The Board of Directors of Stock Exchange has a supervisory role, but in addition to this responsibility, is qualified to handle part of the disputes in the stock exchange. Of course, this jurisdiction is not exclusive and by the decision of the jury, relates to the disputes (Savekoohi, Board of Directors of Stock Exchange).

\subsubsection{The Third Development Plan}

The third development plan enacted in 2000 has dedicated two article to discuss stock exchange and in Article 15 of the fourth development plan enacted in 2004, regulations have been established regarding stock exchange. These discussions relate to the assignment of management stock of government-owned companies in the private sector.

\subsubsection{The Legal Nature of Jury in Stock Exchange}

Regarding the nature of arbitration in stock exchange, this technical question is raised: What is the nature of the jury? Should it be considered as arbitration in line with what the legislature has introduced? Should we find another concept for that, such as specific non-judicial authorities?

\subsubsection{Similarities and Differences of Courts of Justice and Jury}

The beginning of settlement in the jury such as court is required to submit a petition and payment of legal fees. Settlement in the jury is done like judicial courts as substantive mode. In this panel, contacts, transactions and disputes are substantively considered and the final verdict will be announced. The jury in a settlement process cannot take advantage of researches, inquiry and testimony in order to disclose the fact, besides in judicial courts, the judge is required to issue judicial verdict after passing the process. According to the principle 167 of the constitution, "the judge is required to do his best to judge each case based on the codified laws. Otherwise, valid Islamic sources are used." Since the jury handles the disputes substantively based on the law, the final verdict is necessary and its avoidance by the panel is against the law and leads to ambiguity in the dispute and ignoring the rights of the parties. The verdict issued by the jury can be the same as verdicts by the courts. The issued verdict should be reasoned and documented. Principle 166 of the constitution provides: "courts' verdicts should be reasoned and documented regarding the provisions and principles that the verdict has been issued based on them." Therefore, the verdicts of the jury should be based on the domestic laws and regulations and if they are not available, the verdict should be issued based on valid sources of Islamic law (Mirzaei, 2011).

Principle 34 of the constitution provides: "petition is the absolute right of each person and everybody can refer to the courts for petition. All people have the right to have access to these courts and nobody should be banned from them." Also, since public rights restoration, expanding justice, legal freedoms, supporting individual and social rights and realizing justice are among the responsibilities of the judiciary, closures of courts, delay in the formation of the jury or introducing its members ban restoration of people's rights and are not consistent with the principles of the constitution.

Judiciary courts and jury are different in a number of members, expertise and appointment. In public judiciary courts, the judge unity is dominated when the court starts by one judge and the verdict is issued while the jury is consisted of three members. The law graduates after admission in the related exams will be appointed to this job, but the members of jury consist of one judge and two financial and economic experts. Indeed, the jury consists of technical members and related to needs of stock exchange in financial and economic contexts (Ibid).

Regarding the appointment, the judges passing the exam will be appointed by the order of the Head of Judiciary. Two members of the jury (financial and economic experts) will be appointed by the suggestion of the Securities and Stock Exchange Organization without passing the exams.

\subsection{Specific Non-Judicial Authorities}

In defining the specific non-judicial authorities, it should be stated that in these authorities, unlike specific judicial authorities, the members are partly or fully appointed by the executive branch. The nature of the activities of the securities market's jury is related to handling the disputes, investigating the nature of contracts and deals. In other words, in investigating the contracts and deals around the regulations of a market, the jury acts as arbiter like judges of the courts in other contracts and deals. This authority has the jurisdiction to comment on the principles of the contracts between securities market activists and their real or unreal nature or issuing a verdict regarding the obligations resulted from the contracts. But after examining the competence of other specific non-judicial authorities, it is inferred that the nature of their performance does not have this description. For example, the competence of authorities in the implementation of work law is mainly related to the competence of the employment relationship and they vote for condominium partition with the registration 
authorities that is mainly different from arbitration in disputes and issuing a verdict for the compensation of damages with the inference of the contracts between the parties. Finally, it should be stated that the jury has been qualified by the law, but it should be considered as an independent entity, because in addition to the characteristics of its members, according to the Clause 4 of Article 36 of Market Act, the budget of the jury should be paid as the budget of the organization. According to this clause, it is possible to consider jury as the subset of Securities and Stock Exchange Organization. Since the organization is an independent entity, it is not acceptable to consider entities such as jury that provides its budget from the organization as the subset of the executive branch and consider it as a specific non-judicial authority (Davati, 1996).

\subsection{Arbitration}

Of course it is not possible to consider the jury of the stock exchange as a voluntary arbitration, because there are fundamental differences between these two. However, the incompatibility of the stock exchange jury and voluntary arbitration are not clear reasons to issue general verdict, because arbitration is of several types. One type of arbitration is compulsory arbitration that the jury should be considered as its subset. Indeed, since a major part of commercial activities should be done in stock exchange and commercial activities require immediate actions against daily events, the legislature should immediately find an authority to settle the disputes and to avoid likely problems for stock exchange activities. Also, since the role of arbiters has a significant place in the settlement of commercial disputes, it has been taken into consideration. The legislature has been very careful about arbitration to benefit from its specific advantages such as expertise, speed, accuracy and finding a fair and equitable solution without additional costs. In addition to the advantages of arbitration, the presence of an official judge in jury along with two financial and economic experts leads to increased credit of the issued verdicts. Despite the presence of official judge, this panel only has the competency to issue final verdicts that the judiciary judges do not issue. Arbitration according to the specific legal definition is not acceptable for them, because in some cases, the disputes require expertise, speed, accuracy where the government has urged reference to arbitration. The ignorance of arbiters by the members is not a new phenomenon in Iran. The Arbitration Council Law enacted in 1978 predicted an arbitration council consisted of local trustees to handle some of the disputes and issuing an appeal verdict who were selected for a period of four years. The Arbitration Council Formation Law enacted in 1967 also predicted an arbitration council consisting of five local trustees for a period of three years who were allowed to issue verdict in some of civil and criminal cases. The issued verdicts if were confirmed by the consultant, were obligatory and necessary to be implemented, otherwise they could be reviewed in the judiciary (Mohammadi, 2011).

Another critique is that according to Article 470 of Civil Trial Procedure, "all of the judges and staff working in judiciaries cannot make judgments while one of the members of the jury is the judge appointed by the Head of the Judiciary." In this regard, it should be stated that Chapter 7 of the Civil Trial Procedure that is dedicated to arbitration in disputes, has not presented clear definition of arbitration and its types and whether these regulations include various arbitrations or not. But from the sum of regulations of Chapter 7 of Civil Trial Procedures such as Articles 454 and 455, it can be concluded that this chapter is dedicated to voluntary arbitration. Since the Market Act after the Civil Trial Procedure is dominated over it, it is not possible to avoid considering it as arbitration only for the presence of the judge in this panel that is called "jury" by the legislature and to find another concept. For example, it is not possible to consider a judicial aspect of it and state that since there is a judicial judge on this panel who is the head of the panel, he is a judicial authority, because the judge focuses on disputes in this authority, not judicial disputes like what can be observed in judicial courts. Indeed, the judge settles the disputes along with two other members. Fair arbitration is separated from tough rules of Civil Trial Procedure and in addition to what stated, settlement in the jury needs an introduction and disputes before handling in the jury should be proposed in the associations of interest. Settlements in these associations are based on intervention and this means settlement based on compromising. It directs our mind towards achieving the goal of the legislature by the word "arbitration" in introducing stock exchange dispute settlement authority and to induce this feeling that the legislature seeks to necessitate the use of alternative methods for dispute settlement in stock exchange context due to the specific advantages (Mirzaei, 2008).

\subsection{Arbitration Characteristics in Stock Exchange}

Arbitration in stock exchange has specific characteristics that separate it from other types of arbitration:

1) Legal of compulsory: stock exchange arbitration should be considered as compulsory arbitration that the legislature points to it for dispute settlement.

2) Specificity: Principle 159 of the constitution provides: "initial handling of the disputes is within the jurisdiction of public and revolutionary courts, despite in cases where the law has determined another 
authority." Article 39 of Market Act provides: "disputes between brokers, broker/dealers, consultants, investors, issuers, investment and other beneficiaries are handled by the jury if are not settled in associations. This article has specified the qualification of the judiciary courts in handling the disputes. Also, it directs the settlement of disputes resulted from professional activities of market activists to another entity called a jury.

3) Investigating the disputes nature: the jury within its jurisdiction, settles disputes resulted from professional activities of the stock exchange and market activists and the issues verdict in this regard. In other words, the jury settles the disputes by issuing a verdict for financial compensation or rejects the petition. Therefore, in this authority, to identify the reality, a substantive investigation takes place and can take advantage from inquiry and witnesses' testimonies in clarifying the truth (Savekoohi, Board of Directors of Stock Exchange).

\section{Competencies of the Jury}

\subsection{Characteristics}

Competencies refer to the competency features, identification, and authority degree and class. In judiciary authority division, these characteristics are used for separation of competencies of dispute settlement authorities (Fahimi, 2009).

\subsection{Conditions}

By competencies conditions, it means the conditions that the subject and the parties should have to let the jury consider the case.

a. Conditions related to the subject: the subject must be "a legal dispute" resulted from professional activity.

b. Conditions related to the parties: Article 36 of Market Act considers six groups to be proposed in jury: disputes between investors (seller or buyer) and broker, disputes between brokers, disputes between investors and company listed on the stock exchange, disputes between company listed on the stock exchange and the stock exchange itself, disputes between brokers and stock exchange, disputes between investors and the stock exchange (Ibid).

\subsection{Domain}

The disputes in stock exchange, commodity exchange, markets out of the stock exchange, and dispute of Article 43 of Market Act are those disputes that are settled in the stock exchange jury. However, disputes of Principle 139 of the constitution and disputes of Article 21 of the third development plan are the exceptions of this domain that should be considered (Ibid).

\section{Conclusion and Suggestions}

The stock exchange is a place for trade and trading securities. In these trades, some disputes occur between the parties; therefore, an entity is required to settle the disputes resulted from stock exchange deals from the beginning. In the first law of Iran's capital market, an entity has been predicted to settle the disputes and is introduced as one of the four pillars of the stock exchange. By 2005 and enacting Market Act, the Establishment Act was abrogated, but in this Act, the jury has maintained its place as one of the stock exchange pillars and still continues its activity. A specialized authority for the settlement of stock exchange disputes is necessary. Such authority is determined by the legislature with the goal of settling the disputes with speed, accuracy and increasing credits of the stock exchange as well as attracting investors' confidence. Market Act, has assigned dispute settlements to three authorities. These authorities consist of associations, jury and the Stock Exchange of Board of Directors. In sum, it should be stated that considering associations as a settlement authority is beneficial, but it should be considered that dispute settlement in associations do not follow trial rules and procedures. Therefore, each association settles the disputes through the method of interest and this leads to create different procedures in dispute settlement. Therefore, it is suggested to predict uniform rules to increase coordination between the associations. On the other hand, due to the size of the proposed disputes, the legislature in immaterial disputes should give the authority to the associations and exempts the jury from these disputes. The Board of Directors of Stock Exchange has undergone damages due to faults, providing incomplete and untrue information, financing company, auditor, and legal consultants. It has mutual competencies with the jury and this competency is the competency of the jury in the settlement, but cannot be proposed in two authorities. 


\section{References}

Darvishi, Y. (2009). Alternatives for disputes settlements (1st ed.). Mizan Publications, Tehran.

Davati, Gh. (1996). Stock exchange and stock pricing (1st ed.). Mizan Publications, Tehran.

Fahimi, H. (2009). Jury as a fair authority for dispute settlement in capital market. Journal of Stock Exchange, 84.

Langorodi, J. (1998). Law Terminology (9th ed.). Gang-E-Danesh Publications, Tehran, 283.

Madani, J. (2009). Civil Trail Procedure (6th ed.). Paidar Publications, Tehran.

Miraei, Gh. (2011). Stock Exchange Rights (1st ed.). Mizan Publications, Tehran, 114-116.

Mirzaei, Gh. (2007). Criminal Justice of Stock Exchange (1st ed.). Mizan Publication, Tehran.

Mirzaei, Gh. (2008). Dispute settlement in Iran's capital market: comparative study in foreign markets (1st ed.). Tehran.

Mohammadi, M. (2011). Arbitration in Irans'Rights (1st ed.). Behnami Publications, Tehran, 25.

Moien, M. (1984). Moien Dictionary (2nd ed.). Amirkabir Publications, Tehran. 1493.

Savekoohi, S. (n.d.). Board of Directors of Stock Exchange (2nd ed.). Tehran.

\section{Copyrights}

Copyright for this article is retained by the author(s), with first publication rights granted to the journal.

This is an open-access article distributed under the terms and conditions of the Creative Commons Attribution license (http://creativecommons.org/licenses/by/4.0/). 